\title{
Effect of Chloride and Sulfate Ions on the SCC of API-X70 Pipeline Welds in Diluted Carbonated Solutions
}

\author{
M.A. Espinosa-Medina ${ }^{1,{ }^{*},}$, G. Carbajal-De la Torre ${ }^{1}$, A. Sánchez Castillo ${ }^{1}$, C. Ángeles-Chávez ${ }^{2}$, \\ T. Zeferino-Rodríguez ${ }^{3}$, J.G. González-Rodríguez, ${ }^{3}$ \\ ${ }^{1}$ Facultad de Ingeniería Mecánica, UMSNH, C.P. 58000, Morelia, México. \\ ${ }^{2}$ Instituto Mexicano del Petróleo, Gerencia de Desarrollo de Materiales y Productos Quimicos, Eje \\ Central Lazaro Cardenas No. 152, C.P. 07730, Ciudad de Mexico, Mexico. \\ ${ }^{3}$ Centro de Investigación en Ingeniería y Ciencias Aplicadas, UAEM, C.P. 62210, Cuernavaca, \\ México. \\ *E-mail: marespmed@gmail.com
}

doi: $10.20964 / 2017.08 .07$

Received: 19 August 2016 / Accepted: 22 May 2017 / Published: 12 July 2017

The stress corrosion cracking (SCC) susceptibility of longitudinal weldments of API-5L X-70 PSL1 pipeline steel in diluted bicarbonate solutions with and without the addition of chloride and sulfate ions by using slow strain rate tests (SSRTs) has been evaluated. The tests were complemented with potentiodynamic polarization curves, and hydrogen permeation measurements using the DevanathanStachurski method. Solution concentrations varied from 0.1 to $0.0001 \mathrm{M} \mathrm{NaHCO}_{3}$. In addition, chloride $\left(\mathrm{Cl}^{-}\right)$and/or sulfate $\left(\mathrm{SO}_{4}^{2-}\right)$ ions were added to the $0.01 \mathrm{M} \mathrm{NaHCO}$ solution. Results showed a high corrosion rate and an increase in the hydrogen permeability rate in the $0.01 \mathrm{M} \mathrm{NaHCO}_{3}$ solution presented by the welding samples. The addition of $\mathrm{Cl}^{-}$ions increased the activity of the solution, but with the additions of $\mathrm{SO}_{4}^{2-}$ ions, the metallic surface developed a passive layer that was associated with surface crack initiation. Analysis of fractured surfaces showed mainly of ductile rupture, but some indications of micro cracks and quasi-cleavage mode fracture characteristic of hydrogen embrittlement at the weldment were found in both the $0.001 \mathrm{M} \mathrm{NaHCO}_{3}$ and $0.01 \mathrm{M} \mathrm{NaHCO}_{3}$ with $\mathrm{Cl}^{-}+\mathrm{SO}_{4}^{2-}$ ion solutions.

Keywords: API X-70 steel; Stress Corrosion Cracking; Hydrogen permeation; Weldment.

\section{FULL TEXT}

(C) 2017 The Authors. Published by ESG (www.electrochemsci.org). This article is an open access article distributed under the terms and conditions of the Creative Commons Attribution license (http://creativecommons.org/licenses/by/4.0/). 